\title{
Highlights of the Midwinter Meetings of the ACRL Board of Directors
}

The Board of Directors of the Association of College and Research Libraries met twice during the ALA Midwinter Meeting in Washington, D.C.: on Friday, January 6, 1984, and Wednesday, January 11,1984 .

\section{Academic Library Personnel Study Group}

The board approved the request of the Academic Library Personnel Study Group to fund the preparation of a working paper on "the changes to be expected in the full range of academic libraries and institutions, exploring their implications for the role, work, education and training of persons entering the field of librarianship, and suggesting ways in which ACRL can and must help librarians and institutions to address personnel issues." The paper will be prepared prior to the Dallas Conference.

\section{ALA Publishing}

The board expressed support for the direction ALA Publishing is taking in seeking to acquire a proven turnkey order billing system. Such a system is badly needed for the effective control of publishing activities within ALA and the divisions. The board urged the ALA Executive Board to support the proposal financially.

\section{BI Liaison Project}

The board approved a preliminary proposal to the Fund for the Improvement of Post-Secondary Education (FIPSE) for the funding of the final three years of the Bibliographic Instruction Liaison project.

\section{Chapters}

The board approved the petition for the establishment of a North Dakota Chapter.

\section{Continuing Education}

The board approved the motions of the Continuing Education Committee, the Standards and Accreditation Committee, and the Budget and $\mathrm{Fi}$ nance Committee to produce training packages on libraries and accreditation in institutions of higher education that will be distributed to interested groups for self-instruction.

The board approved a revised charge to the Continuing Education Committee to give it broad oversight of the Continuing Education Program (analogous to the publications oversight of the Publications Committee) and approved the charge of a new committee, the CE Program Advisory Committee, which will advise the ACRL Program Officer regarding ACRL professional development programs.

\section{Copyright Committee}

The board requested the Copyright Ccmmittee to prepare an article for $C \& R L$ News regarding the NYU copyright settlement and to advise the membership on its implications for their own copying practices.

\section{Discussion Groups}

The board granted the request of the English and American Literature Discussion Group to charge a fee to its members as necessary to defray the cost of producing and distributing its newsletter. They also encouraged the discussion group to use $C \triangleleft R L$ News as a vehicle for communication among its members.

The board approved the establishment of the Microcomputer Services in Academic Libraries Discussion Group.

\section{Eighteenth-Century STC}

The board approved the request of the Western European Specialists Section to bring a resolution before ALA Council to commend the National Endowment for the Humanities, the Mellon Foundation, the Rockefeller Foundation, and the H.W. Wilson Company for making the EighteenthCentury Short Title Catalogue project possible, and urged their continued support to bring the project to a successful completion in America.

\section{Elections}

The board approved the suggestion of the Appointments and Nominations Committee that candidates for ACRL Vice-President/President Elect submit statements of concern to be published in an appropriate issue of $C \downarrow R L$ News. The statements will also appear on the ballots sent to ACRL members.

\section{Extensions}

The board approved extensions for the following ACRL units: the College Library Standards Committee to June 1985; and the Academic and Research Library Personnel Study Group to June 1985.

\section{J. Morris Jones Divisional Leadership Program}

Program participants Joyce Ball, Sharon Rogers, and Janice Koyama provided reports to the board on the first phase of the ALA Divisional Leadership Enhancement Program. The program, led by consultant Glenn Tucker on January 4-5, began with a general discussion of professional associations and went on to a more specific treatment of such divisional concerns as: financial management, strategic planning, program administration, and infor- 
mation sharing. The reports to the ACRL board, along with the reports of the other divisional boards, will be used by the program's Planning Committee to develop the next phases of the project-training packets for divisional board members and a half-day program for new board members to be held at the 1985 Midwinter Meeting.

\section{Legislation Committee}

The board approved the draft on the resolution of the Higher Education Act Reauthorization submitted to ALA Council.

\section{National Conferences}

The board approved a recommendation that the Fifth National ACRL Conference in April 1989 be held in New Orleans if ALA Annual Conference is not held there in 1988; and that the ACRL Conference be held in Cincinnati if the ALA Conference is in New Orleans.

\section{Nonprint Media Series}

The board approved the recommendation of the Publications Committee that the editor of the series, Jean Farrington, be reappointed for one year, during which time a reevaluation of the series will be undertaken.

\section{Samuel Lazerow Fellowship}

The chair of the Samuel Lazerow Fellowship
Committee, Jay Poole, reported to the board that no award would be granted this year based on the quality of the requests reviewed and the apparent misunderstanding of what technical services includes. The Committee will further define this in a formal report to the board.

\section{Section Publications}

The board referred the draft policy on section newsletter subscriptions for non-section members presented by the Publications Committee to the various sections for review.

\section{Standards and Accreditation Committee}

The board approved the policy statement developed by the Committee relative to requests from non-ALA organizations seeking permission to use the format or language of ACRL standards or guidelines.

\section{Statistics}

The board directed the Task Force on Library Statistics to contract with a non-profit agency to conduct a Fall 1984 test survey of library statistical data gathered from the ACRL 100 Libraries list members, and to oversee the distribution, collection, tabulation, and distribution of the responses.

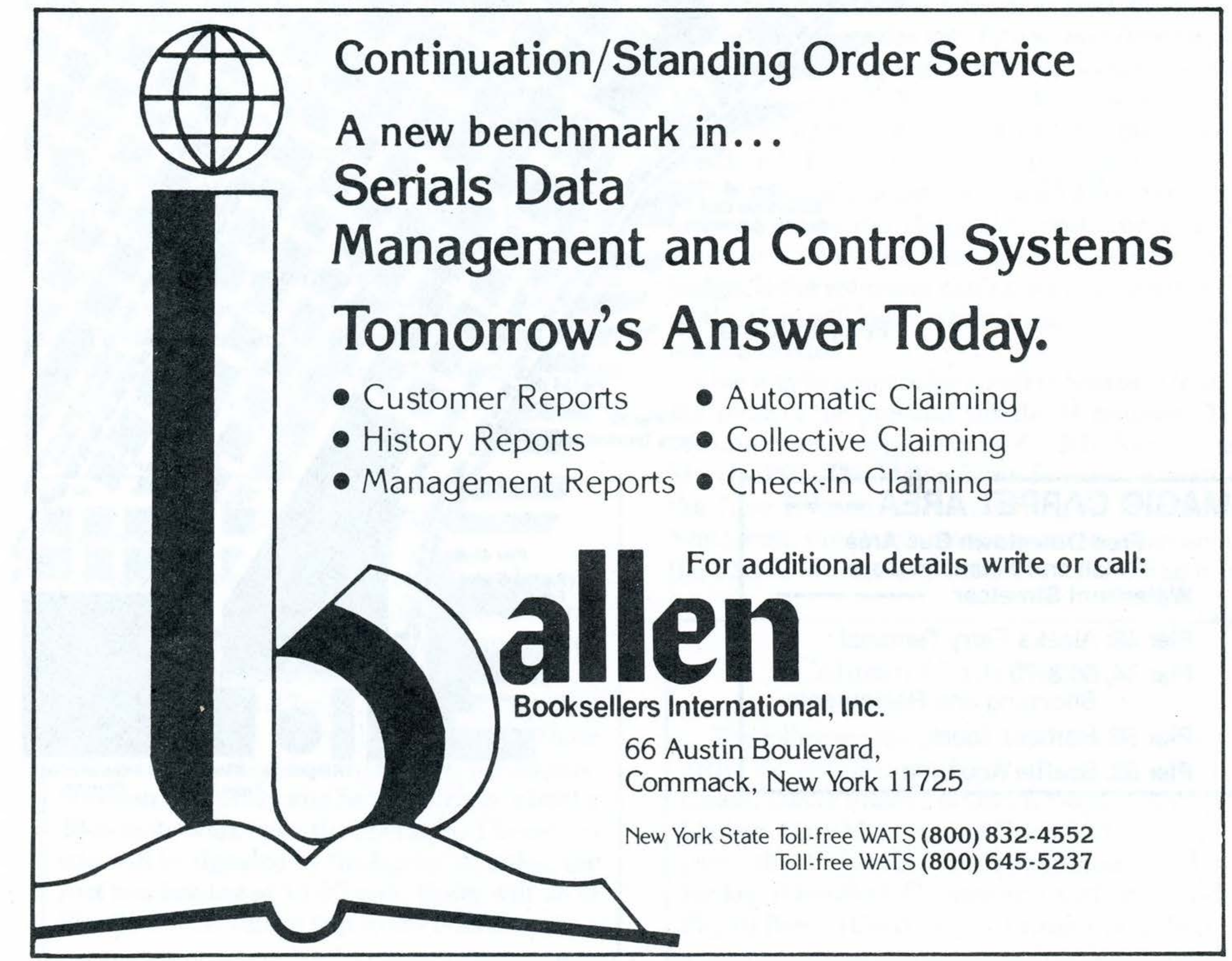




\section{DOWNTOWN SEATIL}

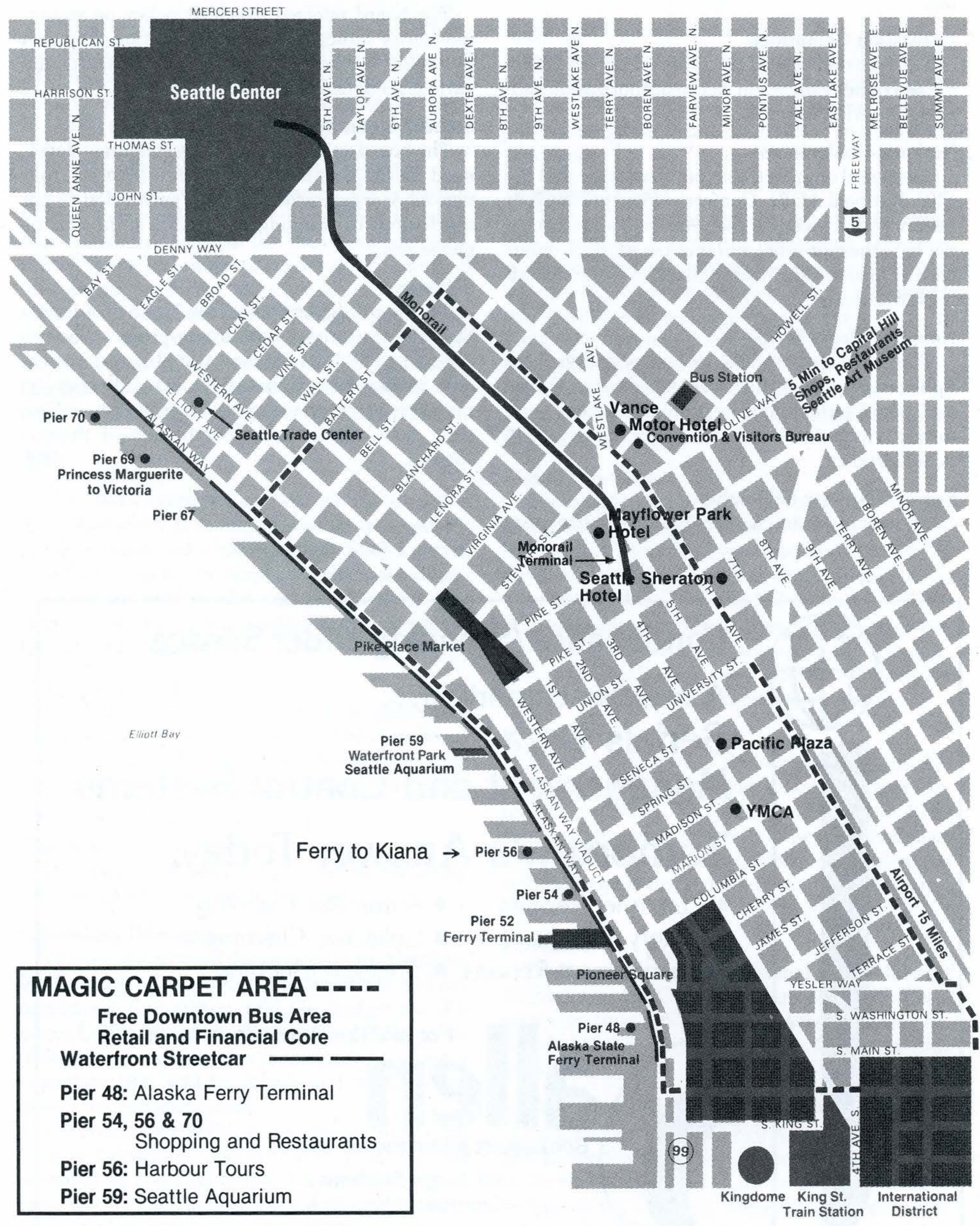

